Abstracta Iranica Abstracta Iranica

Revue bibliographique pour le domaine irano-aryen

Volume 22 | 2001

Comptes rendus des publications de 1999

\title{
L'Imam Khomeyni, un gnostique méconnu du XXe siècle. Beyrouth, Albouraq, 1997, 560 p., index.
}

\section{Charles-Henri de Fouchécour}

\section{(2) OpenEdition \\ 1 Journals}

Édition électronique

URL : http://journals.openedition.org/abstractairanica/36735

DOI : 10.4000/abstractairanica.36735

ISSN : 1961-960X

\section{Éditeur :}

CNRS (UMR 7528 Mondes iraniens et indiens), Éditions de l'IFRI

\section{Édition imprimée}

Date de publication : 15 mai 2001

ISSN : 0240-8910

\section{Référence électronique}

Charles-Henri de Fouchécour, "L'Imam Khomeyni, un gnostique méconnu du XXe siècle. Beyrouth, Albouraq, 1997, 560 p., index. », Abstracta Iranica [En ligne], Volume 22 | 2001, document 323, mis en ligne le 17 février 2010, consulté le 12 octobre 2020. URL : http://journals.openedition.org/ abstractairanica/36735; DOI : https://doi.org/10.4000/abstractairanica.36735

Ce document a été généré automatiquement le 12 octobre 2020.

Tous droits réservés 


\title{
L'Imam Khomeyni, un gnostique méconnu du XXe siècle. Beyrouth, Albouraq, 1997, 560 p., index.
}

\author{
Charles-Henri de Fouchécour
}

1 Le rôle politique de Rūhollāh Homeynī ne doit pas occulter le fait qu'il fut imâm en shi'isme, un titre acquis du fait de son savoir, de sa pensée et de sa vie spirituelle poussés à un degré qui le fit reconnaitre par ses pairs comme l'un des leurs. C'est pourquoi Christian Bonaud a consacré la thèse qu'il publie ici à cet aspect central de la personnalité de l'imâm. Le propos de l'ouvrage est de mettre en relief les traits originaux de la pensée analysée, sur un fond de doctrine hérité, pour l'essentiel, de celle d'Ibn 'Arabī et de la gnose shi'ite de Mollā Șadrā. Les textes qui forment le copus livré à l'enquête sont ceux que l'imâm Homeynī a produits entre l'âge de 27 ans (en 1929) et celui de 43 ans (en 1945). Sous la plume de Ch. Bonaud, la description du parcours scolaire et des disciplines enseignées à l'imâm puis par lui est d'un vif intérêt. L'essentiel de l'ouvrage est ensuite une sorte d'anthologie des textes de l'imâm, commentés de façon fort riche par l'auteur. Si l'ouvrage a évité d'entrer dans le discours politique qui pointe déjà dans la période étudiée, il n'a cependant pas manqué de se mouler dans un certain parti pris qui malmenait la pensée occidentale.

\section{INDEX}

Thèmes : 7. Islam 


\section{AUTEURS}

\section{CHARLES-HENRI DE FOUCHÉCOUR}

Sorbonne Nouvelle - Paris III 